\title{
Analysis of the properties of masonry mortars made with recycled fine aggregates for use as a new building material in Cuba
}

\author{
Análisis de las propiedades de morteros de albañilería fabricados con áridos finos reciclados como \\ un nuevo material de construcción en Cuba
}

Iván Martínez (Main author)

Instituto de Ingeniería, Universidad Nacional Autónoma de México, México DF, México.

iv.martinezh@gmail.com

Miren Etxeberria (Contact author)

Departamento de Ingeniería Civil y Ambiental. Universidad Politécnica de Cataluña, Barcelona, España. C. Jordi Girona, 1-3, Módulo C1, CP: 08034, Barcelona, España.

miren.etxeberria@upc.edu

\section{Elier Pavón}

Centro de las Ciencias Exactas y de las Tecnologías, Universidad Federal del Oeste de Bahía, Brasil.

elier.pavon@ufob.edu.br

\section{Nelson Díaz}

Departamento de Ingeniería Civil, Instituto Superior Politécnico José Antonio Echeverría, La Habana, Cuba. nediaz@cujae.edu.cu

\begin{abstract}
This paper details the research work carried out on masonry mortars produced employing recycled aggregates in $100 \%$ substitution for natural sand aggregates. The main objective of the work being the validation of the resulting recycled aggregate mortar for use as a new construction material in Cuba. The recycled aggregates were acquired from the crushing of demolition material obtained from four different houses of distinct construction types. The work was carried out in two experimental stages. In stage 1, mortars with different percentages of recycled aggregates were produced and analysed. The analysis was carried out in order to achieve the optimal mix dosage, while employing the largest usable volume of recycled aggregates and in compliance with the functional requirements established by Cuban regulations. In stage 2, all mortars were produced employing the defined optimal mix proportion The fresh state properties (water retentivity) and hardened state (flexural, compression and bond strengths and capillary absorption capacity) were evaluated in the mortars produced with the other three mixed recycled aggregates of different compositions. It was concluded that the mortars produced with recycled aggregates needed less filler than that of the control mortar in order to obtain adequate properties in their fresh state. However, these recycled aggregate mortars obtained lower mechanical properties and higher capillary absorption that those of the control mortar. Nevertheless they were in compliance with the minimum requirements established in the Cuban regulation.
\end{abstract}

Keywords: construction and demolition waste, recycled fine aggregate, masonry mortars, properties in fresh and hardened state

\section{Resumen}

En el presente trabajo se detalla la investigación llevada a cabo sobre morteros de albañilería utilizando áridos reciclados en sustitución al 100\% de la arena natural. El objetivo principal del trabajo es la validación del mortero fabricado con árido reciclado como nuevo material de construcción en Cuba. Los áridos reciclados fueron obtenidos de la trituración del material de demolición de cuatro tipos de viviendas de diferente tipología de construcción. El trabajo se llevó a cabo en dos etapas experimentales. En la etapa 1, se fabricaron y analizaron morteros fabricados con diferentes porcentajes de un tipo de árido reciclado. El análisis se llevó a cabo con el fin de obtener la dosificación óptima del mortero utilizando el mayor porcentaje de árido reciclado posible y en cumplimiento con los requerimientos establecidos por las normas cubanas. En la etapa 2 , todos los morteros se fabricaron utilizando la óptima dosificación definida en la etapa anterior. En cada mortero fabricado con los otros tres tipos de áridos reciclados obtenidos, se determinó la retención de agua en estado fresco, y las propiedades de resistencia a flexión, compresión y adherencia así como la absorción capilar en estado endurecido. Se concluyó que los morteros producidos con árido reciclados necesitan menos filler que el de mortero de control para obtener adecuadas propiedades en estado fresco. Sin embargo, los morteros fabricados con árido reciclados obtuvieron menores propiedades mecánicas y mayor absorción capilar que el obtenido por el mortero de control. No obstante todos los morteros fabricados con árido reciclado alcanzaron los límites establecidos por la normativa cubana. 


\section{Introduction}

The city of Havana is comprised of a variety of types of dwellings of distinct architectural styles in which diverse materials have been employed in their construction. A high percentage of these constructions have fulfilled their useful life cycle and are at present in poor condition.

Based on the data recorded by the National Statistics Office (ONE), it is estimated that the daily generation of waste from construction and demolition works (CDW) in the city exceeds 1000 m3 (Manchon, 2010; Pavon et al, 2012;. Pavón et al., 2014). Most of this CDW is deposited in common landfills, causing contamination as well as inhibiting later use. This situation is mainly due to the lack of adequate technological infrastructure and poor policy decisions in the management of this waste.

The uncontaminated CDW existing in Havana is mostly of a mixed type, due to the absence of selective demolitions (Figure 1). The resulting CDW contains materials of different natures (ceramic, concrete, mortar, lime, etc.), which require the development of treatment applications that contribute to a sustainable development of the city. In the majority of the capital's buildings, the vertical construction elements are comprised of concrete blocks bonded with masonry mortar. Masonry mortar is also used for the external and internal rendering of these walls, which leads to the consequent need to employ a large volume of natural aggregates in their manufacture.

One of the great problems facing construction works in Havana is that the nearby quarries where the natural aggregates are obtained are overexploited and many are beginning to be depleted. The outcome of this is that the quarries that supply the capital are becoming increasingly more distant, with the consequent effect of the increasing transportation costs of these materials.

The manufacture of recycled aggregates from the CDW generated in the city is an alternative which will permit the protection of natural resources, by not only reducing the quarrying and transport costs, but also the all important minimization of the environmental impact caused by the irregular deposition of CDW (Muñoz Fernandez, 2012; Pavon et al, 2012).

The great majority of research concerning the reuse of CDW deals with its application in the manufacture of concrete (Corinaldesi, 2010; Evangelista \& Brito, 2010; Kou \& Poon, 2012;. Pavon et al, 2011). However, due to the great importance of the use of masonry mortar in the construction of buildings carried out in Havana, it was considered essential to analyse the applicability of recycled fine aggregate in the manufacture of these mortars.

In accordance with the research work carried out so far in Havana, it can be observed that the replacement of natural aggregate for recycled aggregate in the production of masonry mortars has not only reduced the transport costs of the natural aggregates but also avoided the overexploitation of the quarries. Moreover, it must be noted that the environmental impact of the irregular deposition of these residues in natural areas (Muñoz Fernández, 2012) has been minimized.

Up until now, there has been little research work carried out in the area we are dealing with. Amongst the studies that do exist, it was stated that the substitution of $25 \%$ of natural sand for recycled fine aggregate would not significantly affect the properties of the mortars. It was also stated that the properties that limit its percentage of utilization are the recycled aggregates' high capacity of water absorption and the high sulphate content (Vegas et al., 2009).

Corinaldesi and Moriconi (2009) used recycled aggregates obtained from waste concrete, ceramic and mixed waste materials to produce recycled aggregate mortar. The results revealed that the mortars containing recycled aggregates proved to have a lower mechanical resistance when compared to mortars produced employing natural sand. However, the results also revealed that there was greater bond strength of the mortar interface to the brick in recycled aggregate mortars.

Although, in certain studies, it has been found that higher mechanical strength has been obtained in mortars produced with $100 \%$ substitution of natural aggregates for recycled aggregate (Neno et al., 2014), the most common finding is that a decrease in the mechanical properties is produced with respect to that of conventional mortar ( Martinez et al, 2013;. Zhao et al, 2015). This decrease is mainly due to the increased absorption capacity of the recycled aggregates and the consequent increase in the water / cement ratio of the mortars (Cuenca-Moyano et al., 2014).

In this research work, the demolition waste obtained from four different dwellings of differing construction typologies (commonly employed in Havana) was used to obtain the four types of mixed recycled aggregates, RA0, RA1, RA2 and RA3. These mixed recycled aggregates were later employed in the production of masonry mortars. The experimental phase was conducted in two stages: stage 1 and stage 2 .

Stage 1, consisted in the production and validating of a building mortar comprised of optimal mix proportions, which would not only permit the maximum employment of the recycled aggregate type RAO, but also comply with the requirements established by 
the Cuban regulations.--In stage 2, the optimal dosage obtained from stage1 (that which permitted the use of the largest volume of recycled aggregate) was used as a base on which to analyse the properties obtained in mortars made with the other three types of recycled aggregates, RA1, RA2 and RA3. The obtained results of those recycled aggregate mortars were compared with those of the control mortar (CM) produced employing natural aggregates and with the required values defined by Cuban regulations.

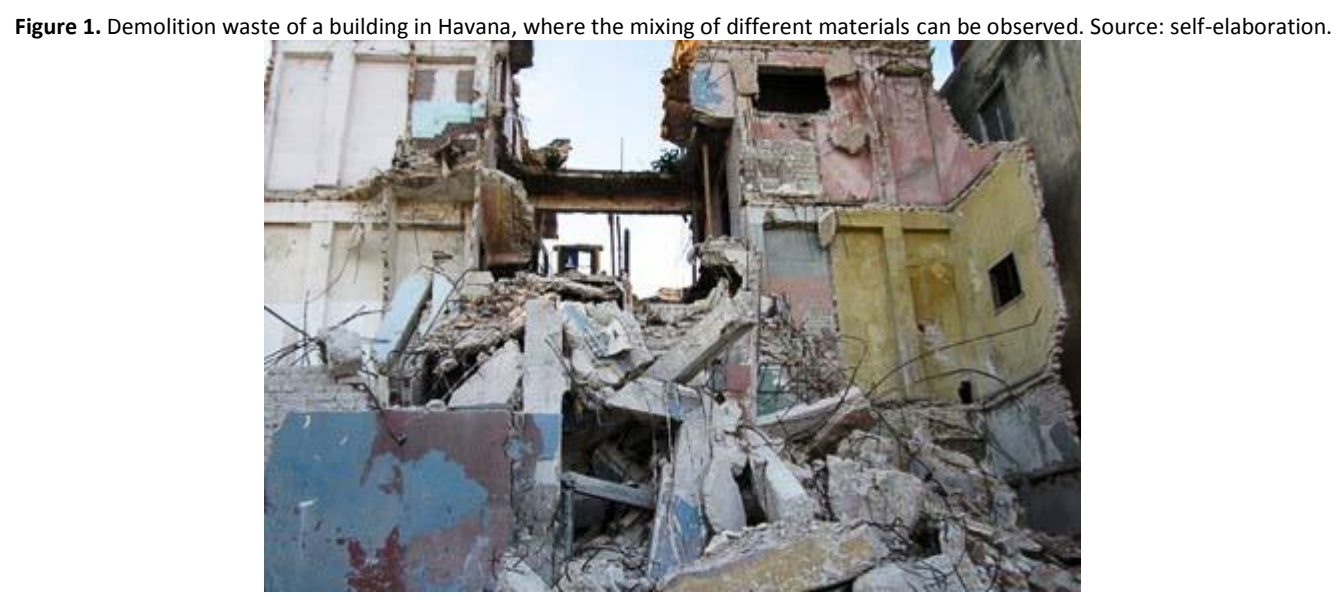

Materials

\section{Cement}

Portland cement P-350 (35 MPa average compressive strength at 28 days), being the highest strength cement marketed in Havana was employed in the production of all mortars. The cement composition is detailed in Table 1.

Table 1. Chemical composition of cement. Source: self-elaboration
\begin{tabular}{|l|l|}
\hline Elements & Results (wt.\%) \\
\hline $\mathrm{SO}_{3}$ & 3,10 \\
\hline $\mathrm{MgO}$ & 1,81 \\
\hline $\mathrm{CaO}$ & 60,65 \\
\hline $\mathrm{SiO}_{2}$ & 20,83 \\
\hline $\mathrm{Fe}_{2} \mathrm{O}_{3}$ & 4,09 \\
\hline $\mathrm{Al}_{2} \mathrm{O}_{3}$ & 3,85 \\
\hline $\mathrm{Na}_{2} \mathrm{O}$ & 0,53 \\
\hline $\mathrm{K}_{2} \mathrm{O}$ & 0,42 \\
\hline Free lime & 1,29 \\
\hline Insoluble residue & 1,46 \\
\hline Ignition loss & 3,56 \\
\hline
\end{tabular}

\section{Construction and demolition waste (CDW)}

The CDW employed in this present research work was obtained from the demolition of dwellings of a representative construction typology widely employed within Havana. Table 2 indicates the composition of each CDW source.

Table 2. Composition of the CDW used. Source: self-elaboration.

\begin{tabular}{|c|c|c|c|c|c|}
\hline \multirow{2}{*}{ Source } & \multicolumn{5}{|c|}{ Composition (wt.\%) } \\
\hline & Ceramic & Mortar & Concrete & Limestone & Mixed* \\
\hline CDWO & 18 & 31 & 40 & 0 & 11 \\
\hline CDW1 & 32 & 28 & 17 & 11 & 12 \\
\hline CDW2 & 11 & 20 & 63 & 0 & 6 \\
\hline CDW3 & 7 & 55 & 1 & 6 & 31 \\
\hline
\end{tabular}

The recycled aggregates employed in this research work were obtained from the crushing of the CDW. A mechanical jaw crusher of laboratory scale was employed for this purpose. The mentioned crusher features an input opening of $25 \mathrm{~cm}$ length and $12.5 \mathrm{~cm}$ width with a maximum output opening (maximum jaw separation) of $10 \mathrm{~mm}$ and a minimum (minimum jaw separation) of $2 \mathrm{~mm}$. The crusher crushes and grinds the material via the use of the two steel jaws (one fixed and one movable). 


\section{Aggregates}

In this research study it was decided to use natural sand (NA) from the Victoria II quarry, Havana, which is the main supplier of aggregates to the capital. Four different types of recycled aggregates RA0, RA1, RA2, RA3, which were obtained from the crushing of different compositions of mixed CDW. Each recycled aggregate is identified with the same number as the source of CDW it was obtained from. Table 3 indicates the results of the chemical analysis of both the fine aggregates and the limestone filler (LF). A limestone filler extensively marketed within Havana was employed in the production of all mortars.

Table 3. Chemical composition of the recycled aggregates and limestone filler. Source: self-elaboration.

\begin{tabular}{|l|l|l|l|l|l|}
\hline Elements & RA0 (wt.\%) & RA1 (wt.\%) & RA2 (wt.\%) & RA3 (wt.\%) & LF (wt.\%) \\
\hline $\mathrm{SiO}_{2}$ & 10,80 & 19,12 & 8,62 & 9,09 & 5,72 \\
\hline $\mathrm{Fe}_{2} \mathrm{O}_{3}$ & 3,13 & 2,41 & 1,14 & 1,46 & 1,60 \\
\hline $\mathrm{Al}_{2} \mathrm{O}_{3}$ & 3,21 & 5,34 & 2,35 & 2,69 & 2,95 \\
\hline $\mathrm{CaO}$ & 43,53 & 61,99 & 52,53 & 51,9 & 47,36 \\
\hline $\mathrm{MgO}$ & 1,54 & 1,53 & 1,15 & 1,61 & 1,79 \\
\hline $\mathrm{Na}_{2} \mathrm{O}$ & 0,30 & 0,48 & 0,35 & 0,26 & 0,11 \\
\hline $\mathrm{K}_{2} \mathrm{O}$ & 0,34 & 0,88 & 0,25 & 0,25 & 0,19 \\
\hline $\mathrm{SO}_{3}$ & 0,67 & 1,65 & 0,57 & 0,53 & 0,17 \\
\hline
\end{tabular}

The recycled aggregates were found to be composed of mainly calcium oxide, which was to be expected, due to the use of limestone aggregates in the majority of the mortars, concrete and masonry elements manufactured within the city. It must be noted that the RA1 aggregate had a high concentration of $\mathrm{SiO} 2$ and $\mathrm{Al} 2 \mathrm{O} 3$ due to the high presence of ceramic material in its composition. It is also important to note that the RA1 had a content of SO3 superior to that of $1 \%$ within its chemical composition. However, it was decided not to limit the use of this aggregate in the production of mortars due to the low percentage of alumina present within the cement manufactured today in the Mariel factory (table 1). These alumina percentages represent similar values to all the P-350 cements marketed in Cuba.

Figure 2 details the particle size distribution of the aggregates. This was determined in accordance with the Cuban regulation NC 178: 2002. One can observe that the particle size of the recycled aggregates studied borders on the lowest particle size limit of the grading distribution values' requirements established by regulation NC 657: 2008 .

Figure 2. Particle size distribution of natural and recycled aggregates. Source: self-elaboration.

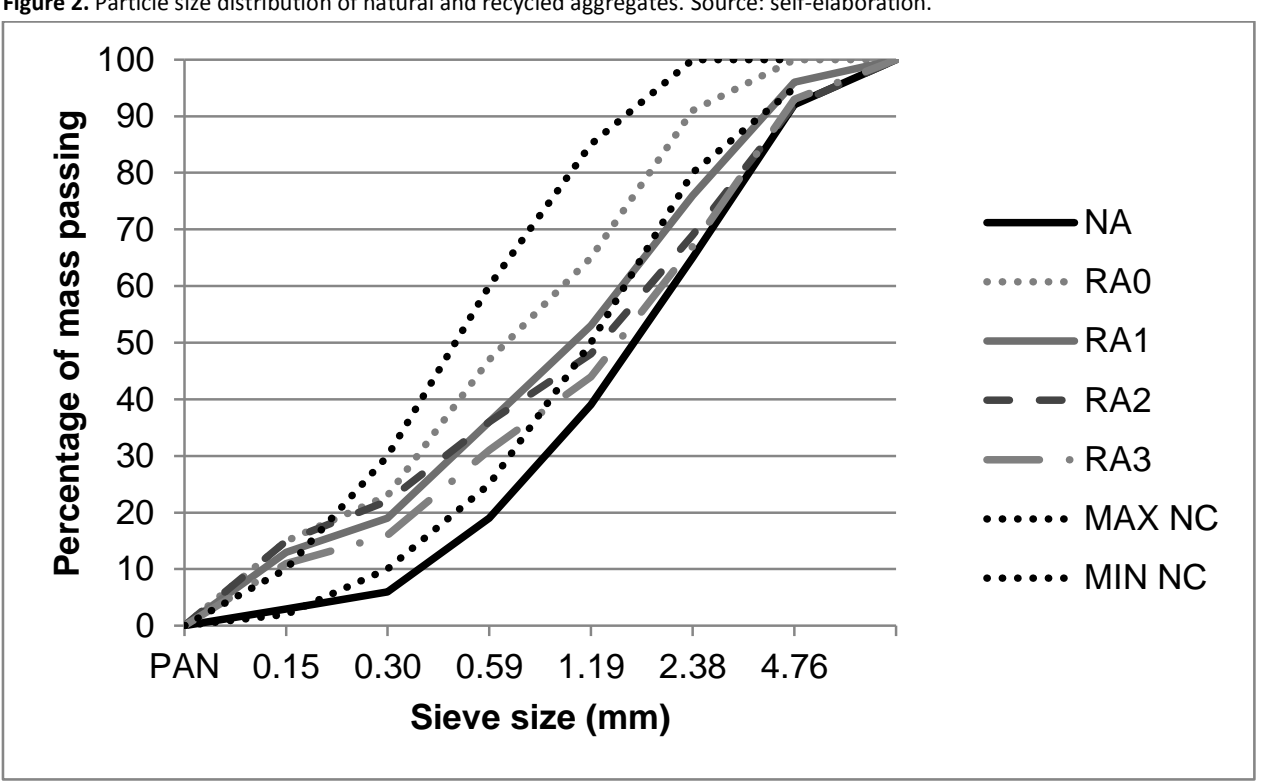

One can observe that the recycled aggregates exhibited a lower fineness modulus to that of the natural aggregate (Table 4), this was due to the higher content of finer materials in those aggregates, which is reflected in the size dimensions starting from the $0,59 \mathrm{~mm}$ sieve (Figure 2). Natural sand is the aggregate which is most commonly employed in the manufacture of mortars within the city. However, the high fineness modulus of this aggregate (caused by the lack of fine particles) implicates the use of a significant amount of filler to fill the voids produced by using only large size grain aggregates. 
Table 4 indicates the physical properties of the aggregates and the limestone filler used. The determination of the density and the absorption capacity of the aggregates was carried out in accordance with regulation NC 177: 2002. The determination of the bulk density in accordance with regulation NC 181: 2002, and the volumetric amount for material finer than sieve 200 in accordance with regulation NC 182: 2002.

Table 4. Physical properties of aggregates and limestone filler. Source: self-elaboration.

\begin{tabular}{|l|l|l|l|l|l|l|}
\hline Properties & NA & RA0 & RA1 & RA2 & RA3 & LF \\
\hline Density $\left(\mathbf{k g} / \mathbf{d m}^{\mathbf{3}}\right)$ & 2,42 & 2,23 & 1,90 & 1,94 & 2,06 & 2,53 \\
\hline Water absorption (\%) & 2,5 & 7,5 & 4,76 & 6,79 & 9,03 & - \\
\hline Bulk density (kg/dm $\mathbf{3})$ & 1,44 & 1,28 & 1,15 & 1.16 & 1,31 & 1,14 \\
\hline Material finer than $\mathbf{0 , 0 7 4 m m}$ sieve (\%) & 4,4 & 13,8 & 12,7 & 11,3 & 7,6 & 37,2 \\
\hline Fineness modulus & 3,5 & 2,6 & 3,1 & 3,2 & 3,4 & - \\
\hline
\end{tabular}

The density of the recycled aggregates proved to be lower than that of the natural aggregates in all the cases studied. The lowest values were obtained from the aggregate whose composition was mainly mortar. The absorption capacity of the recycled aggregates was the property which showed the greatest differences with respect to that of the natural aggregate. In fact it reached levels of being up to 3 times greater in the case of recycled aggregates with a higher presence of concrete or mortar. In general the results of the density and water absorption values achieved in this work were similar to those same values determined in other studies on the employment of recycled aggregates for mortar production (Miranda \& Selmo, 2006a; Vegas et al., 2009).

All the recycled aggregates tested proved to have a high percentage of finer material than sieve \# 200 , exceeding the limit of $10 \%$ established in the Cuban regulations for their use in masonry mortars. However, values of up to $15 \%$ are permitted by the same regulation providing that the aggregates are free of clay, as was the case of all the aggregates studied.

Experimental phase As mentioned above, the experimental phase was carried out in two experimental stages. Stage 1 consisted in the production and validating of a building mortar comprised of optimal mix proportions, which would not only permit the maximum employment of the recycled aggregate type RA0, but also comply with the requirements established by the Cuban regulations.

This was carried out by the production and testing of mortars using differing percentages of RAO in substitution of natural aggregates. In stage 2, the optimal mix proportion defined in stage 1 was employed to produce mortars using the three remaining recycled aggregates, RA1, RA2 and RA3 in substitution for natural aggregates. The resulting mortars were analysed and the test results were compared with the required values established by the Cuban regulation as well as with the results obtained from the control mortar (CM) produced with natural sand.

All the produced mortars worked with a constant flow $(185 \mathrm{~mm}-195 \mathrm{~mm})$ in compliance with the Cuban regulation NC $170: 2002$. This value was achieved by varying the water / cement ratio without having to employ admixtures. All the mortars were tested in their fresh state for fluidity in compliance with Cuban regulation NC 175: 2002, and water retentivity in compliance with Cuban regulation NC 169: 2002. The curing of the mortar was carried out in a humid environment up to the age of testing (NC 173: 2002). The four properties of capillary absorption (NC 171: 2002), flexural and compression (NC 173: 2002) strength and bond tensile strength (NC 172: 2002) were tested in the mortar's hardened condition in compliance with the stipulated Cuban regulations.

The Cuban regulation (NC 172: 2002) regulating the procedure for carrying out the bond tensile test does not establish the exact conditions for its evaluation. In this study, the mortar produced was employed in the construction of a concrete block wall, which is the most common construction typology used today in Havana for the building of walls. The mortar was left exposed to the environment without additional protection or curing until its testing at 28 days.

\section{Step 1. Finding the optimal mix proportion}

The Cuban regulation NC 175: 2002, establishes different volumetric mix proportions in accordance with the different uses of the masonry mortars. For type III (bonding and rendering mortar used at ground level and above) a volumetric dosage of 1:4: 2 (cement: sand: hydrated lime) is recommended. The mentioned dosage was employed in the production of the control mortar (CM) employed within this study, with the exception of the substitution of the hydrated lime for a limestone filler (the limestone filler being the most marketed within the city).

The adequate volumetric dosing for type III standard mortar is a 1: 6 (cement: natural aggregate), however, due to the lack of fine material in the natural sand it is necessary to use a filler, consequently the dosage pattern was changed to 1: 4: 2 . 
Different proportions of RAO recycled aggregates in substitution for natural aggregates were employed in the production of various mortars. In order to obtain the maximum use of the RAO recycled aggregates the study began with a volumetric dosing of $1: 6$ (cement: recycled aggregate). The reason for employing a higher amount of recycled aggregates (the volumetric dosing of $\mathrm{CM}$ mortar employing natural sand aggregate is $1: 4: 2$ ) was due to the amount of finer material within its composition.

As Table 5 shows, the recycled aggregate was gradually replaced by limestone filler until reaching the dosage level, that not only complied with the Cuban regulation (NC 175: 2002), but also employed the maximum amount of RAO recycled aggregates.

Table 5. Mix proportions used in the first stage of the study. Source: self-elaboration.

\begin{tabular}{|l|l|l|l|}
\hline Volumetric dosage & Substitución (\%) & w/c & Nomenclature \\
\hline $1: 6: 0(\mathrm{C}: \mathrm{RA}: \mathrm{F})^{*}$ & 0 & 1,55 & M0_0 \\
\hline $1: 5,7: 0,3$ & 5 & 1,57 & $\mathrm{M} 0 \_5$ \\
\hline $1: 5,4: 0,6$ & 10 & 1,58 & M0_10 \\
\hline $1: 5,1: 0,9$ & 15 & 1,59 & M0_15 \\
\hline $1: 4,8: 1,2$ & 20 & 1,60 & M0_20 \\
\hline
\end{tabular}

${ }^{*} \mathrm{C}$ : Cement; RA: Recycled aggregate; F: Filler

Tests were performed on the fresh and hardened state of the mortars in order to validate the optimal dosage of the four mortars produced. All mortars were produced to work with a fluidity of $190 \mathrm{~mm}$ on the flow table, and the water retentivity was analysed in each of the mixtures produced. As indicated in Figure 3, the substitution of recycled aggregates for limestone filler resulted in increased water retention within the produced mortars. The water retention reached the $90 \%$ limit established by the regulation concerning mortars produced with a substitution of $15 \%$ of recycled aggregates for filler.

Figure 3. Water retentivity of mortars with different percentages of recycled aggregates replacement. Source: self-elaboration.

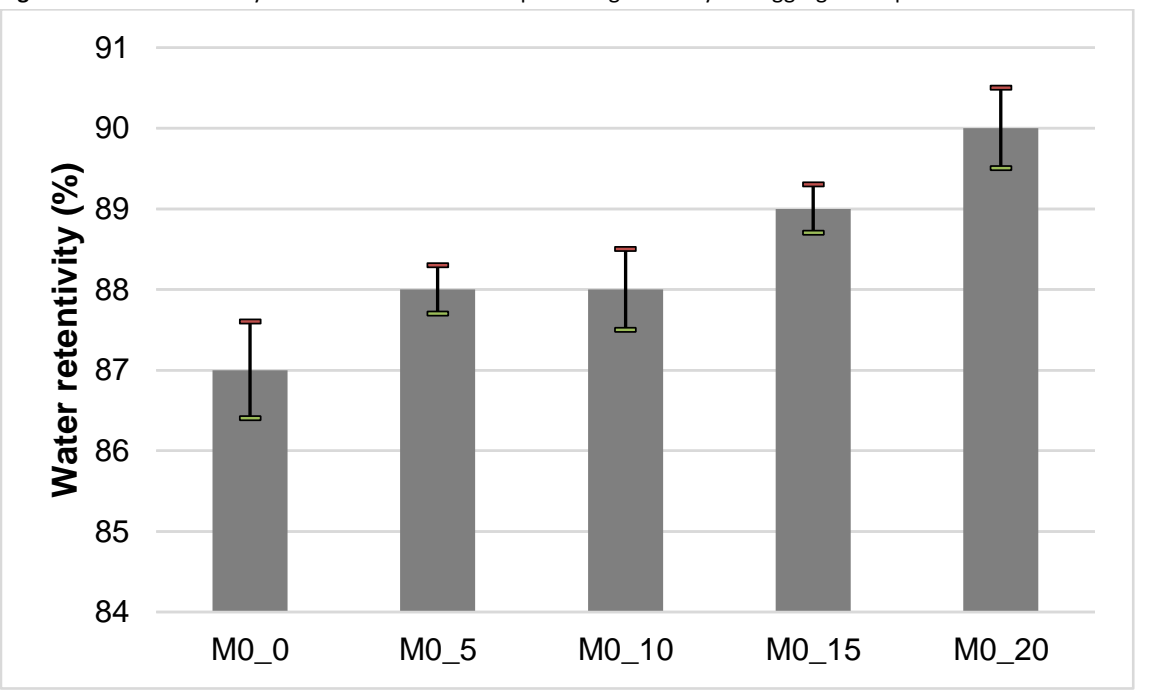

In accordance with the results obtained on the hardened state properties of the mortar, the Cuban regulation NC 175: 2002 indicates that the compressive strength of the mortars at 28 days must be greater than $5.2 \mathrm{MPa}$. Figure 4 indicates that both mortar M0_20 (11\%) and M0_15 (17\%) exceeded this value of compressive strength at 28 days. 
Figure 4. Compressive strength (average, maximum and minimum values) of mortars with different percentage of recycled aggregate replacement. Source: selfelaboration.

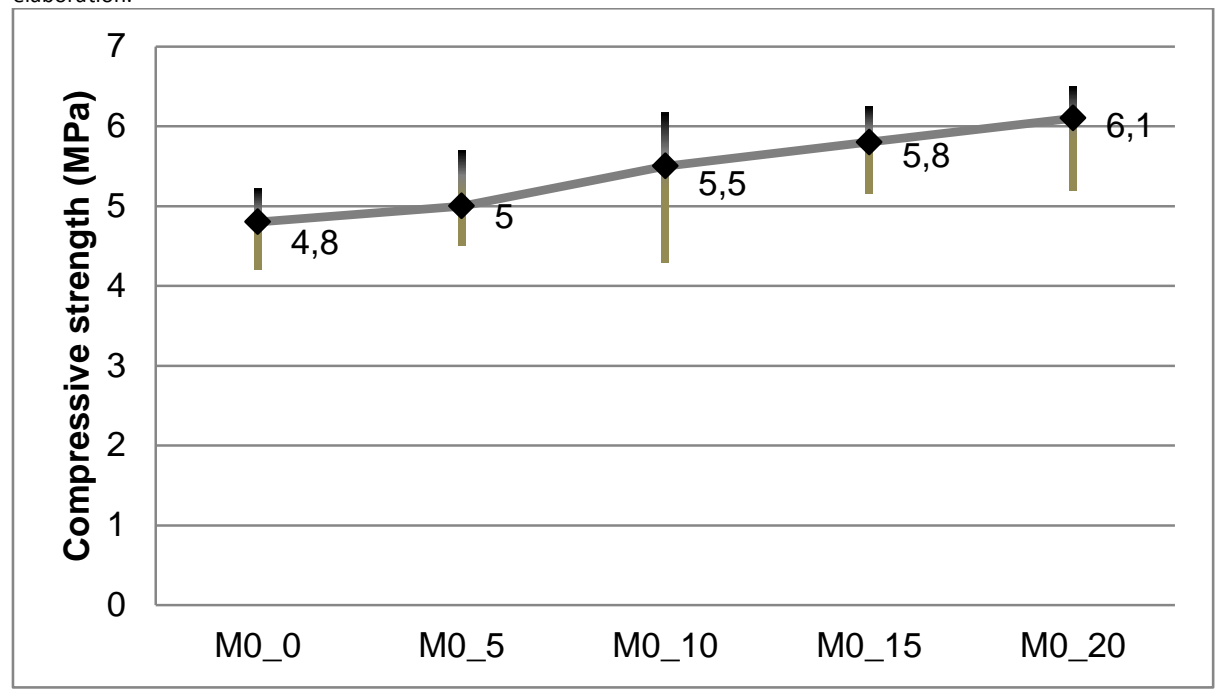

In addition, the bond tensile strength is another property that defines the application of rendering mortars. The results obtained (Figure 5) indicate that the mortars M_15 and M_20 exceeded $0.2 \mathrm{MPa}$ and could be used as rendering mortar for interior walls above ground level, which is one of the main applications ef masonry mortars.

Figure 5. Bond tensile strength of first stage mortars. Source: self-elaboration.

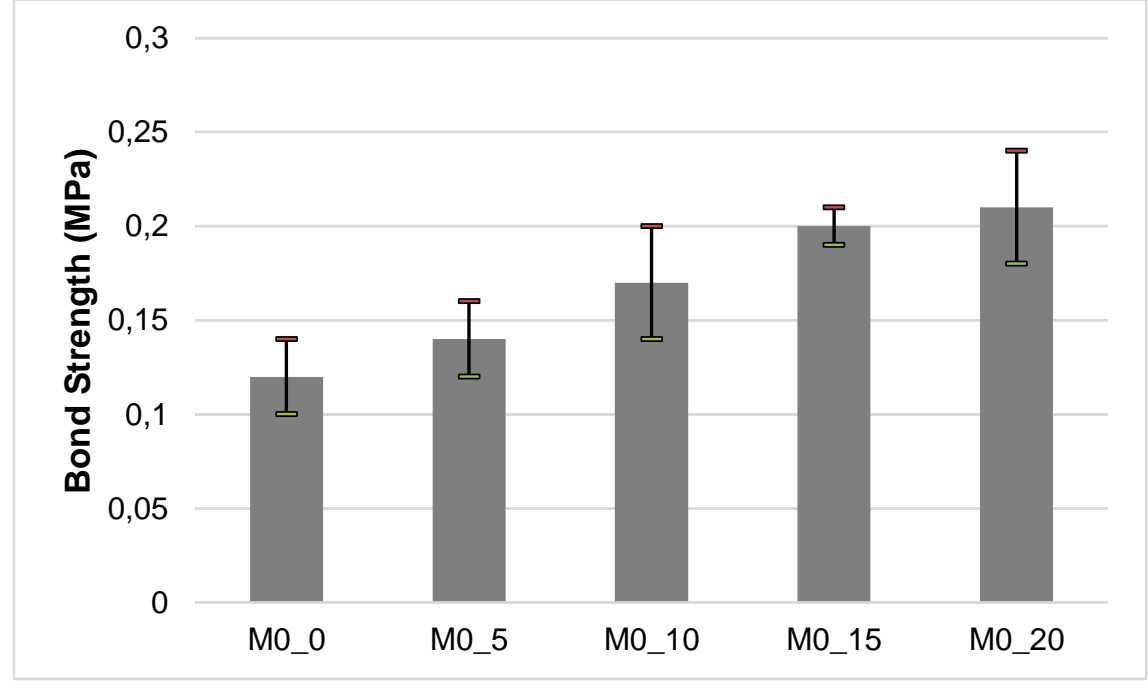

In accordance with the results obtained on the evaluation of the dosages, it was concluded that with the substitution of recycled aggregates for percentages of limestone filler between $15 \%$ and $20 \%$ it was possible to achieve mortars that met the requirements established by the Cuban regulation for use as Type III mortars (in interior renderings).

\section{Stage 2}

The suitable dosages obtained in stage 1 were defined as volumetric dosages 1: 5,1: 0,9 and 1: 4,8: 1,2 (cement:sand:limestone filler, M_15 and M_20 mortar respectively). These two mortars met the functional requirements detailed in Cuban regulation NC 175: 2002. For this study, a volumetric dosage of 1: 5: 1 (cement: recycled aggregate: limestone filler) was employed, which was an intermediate value between the M_20 and M_15 mortars. In a future application it would be feasible to work with whole numbers and proportions, thus facilitating the possibility of producing the mortar on site.

In stage 2, as detailed in Table 6, mortars were produced using the recycled aggregates RA1, RA2 and RA3. It can be observed that in order to obtain the consistency of $190 \mathrm{~mm}$ on the flow table, the mortars produced with recycled aggregates that contained higher quantities of material finer than $75 \mu \mathrm{m}$ needed more water to reach an acceptable level of workability, thus increasing the water cement ratio. 
Table 6. Mix proportions of mortars used in the second stage of the study. Source: Self-elaboration.

\begin{tabular}{|l|l|l|l|}
\hline Nomenclature & Volumetric dosage & Aggregate & w/c \\
\hline M1 & $1: 5: 1$ & RA1 & 1,45 \\
\hline M2 & $1: 5: 1$ & RA2 & 1,42 \\
\hline M3 & $1: 5: 1$ & RA3 & 1,40 \\
\hline CM & $1: 4: 2$ & NA & 1,35 \\
\hline
\end{tabular}

The mortars' water retentivity was studied during the fresh stage of the mixtures, having obtained a workability of $190 \mathrm{~mm}$ on the flow table. The resistance to compression, flexural and adhesion were analysed in the mortars' hardened state. The results obtained by the mortars produced with the recycled aggregates were then compared with those obtained from the control mortar $\mathrm{CM}$ (employing natural sand) as well as the requirements defined by Cuban regulations for type III masonry mortars (bonding and rendering mortar used at ground level and above).

Results and discussion

In Figure 6, one can observe that the water retentivity values obtained by mortars containing recycled aggregates were above those obtained by the $\mathrm{CM}$ control mortar. In comparison with the natural sand the recycled aggregates were found to contain a higher amount of fine material and this contributed to the higher water retentivity values of the recycled aggregate mortars. This behaviour has also been reported in other works studied, achieving increases in the water retentivity of the mortars with incorporation of recycled aggregates (Martinez et al, 2012;. Silva et al., 2010).

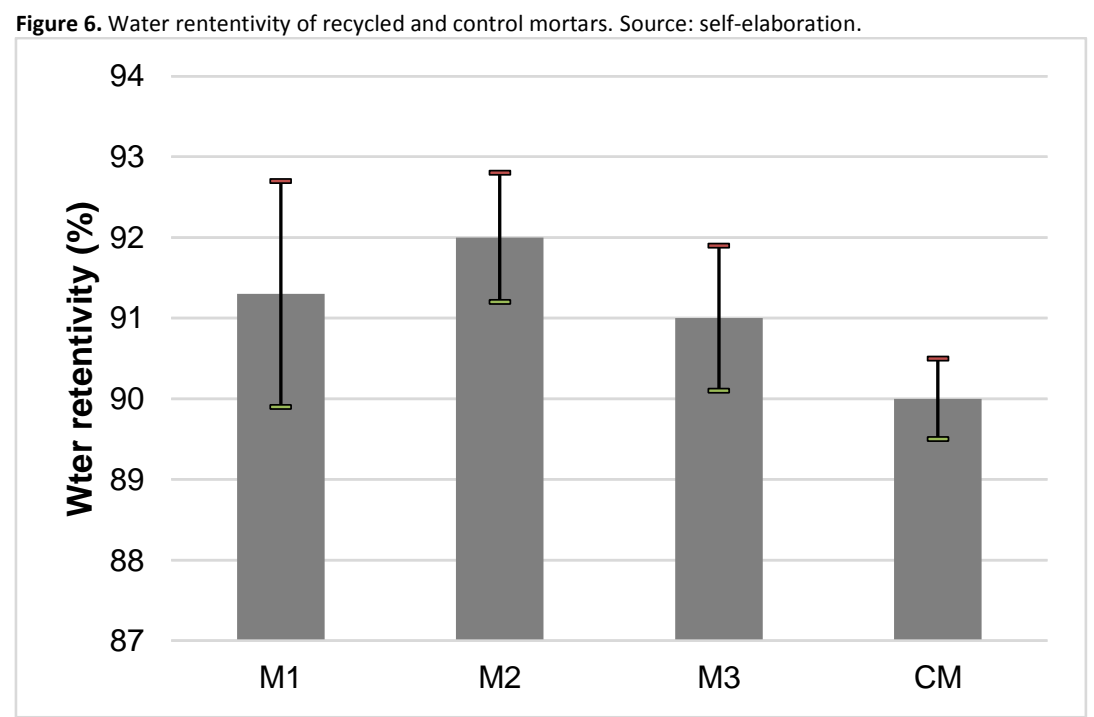

The capillary absorption values obtained by both the control mortar and the recycled aggregates' mortars are indicated in Figure 7 . With respect to this property, the M2 mortar achieved the highest standard deviation value $(0.37 \mathrm{~g} / \mathrm{cm} 2)$ at 24 hours of testing. It was also observed that the M1 mortar obtained a standard deviation of $0.34 \mathrm{~g} / \mathrm{cm} 2$ at 24 hours of testing. In the case of the recycled aggregate mortar $\mathrm{M} 3$ and the control mortar $\mathrm{CM}$, the maximum deviation occurred at 8 hours of testing. In the case of the $\mathrm{M} 3$ recycled aggregate mortar, the value stood at $0.27 \mathrm{~g} / \mathrm{cm} 2$, while the value of the control mortar $\mathrm{CM}$ did not exceed $010 \mathrm{~g} /$ $\mathrm{cm} 2$. 
Figure 7. Water absorption by capillarity of recycled and control mortars. Source: self-elaboration.

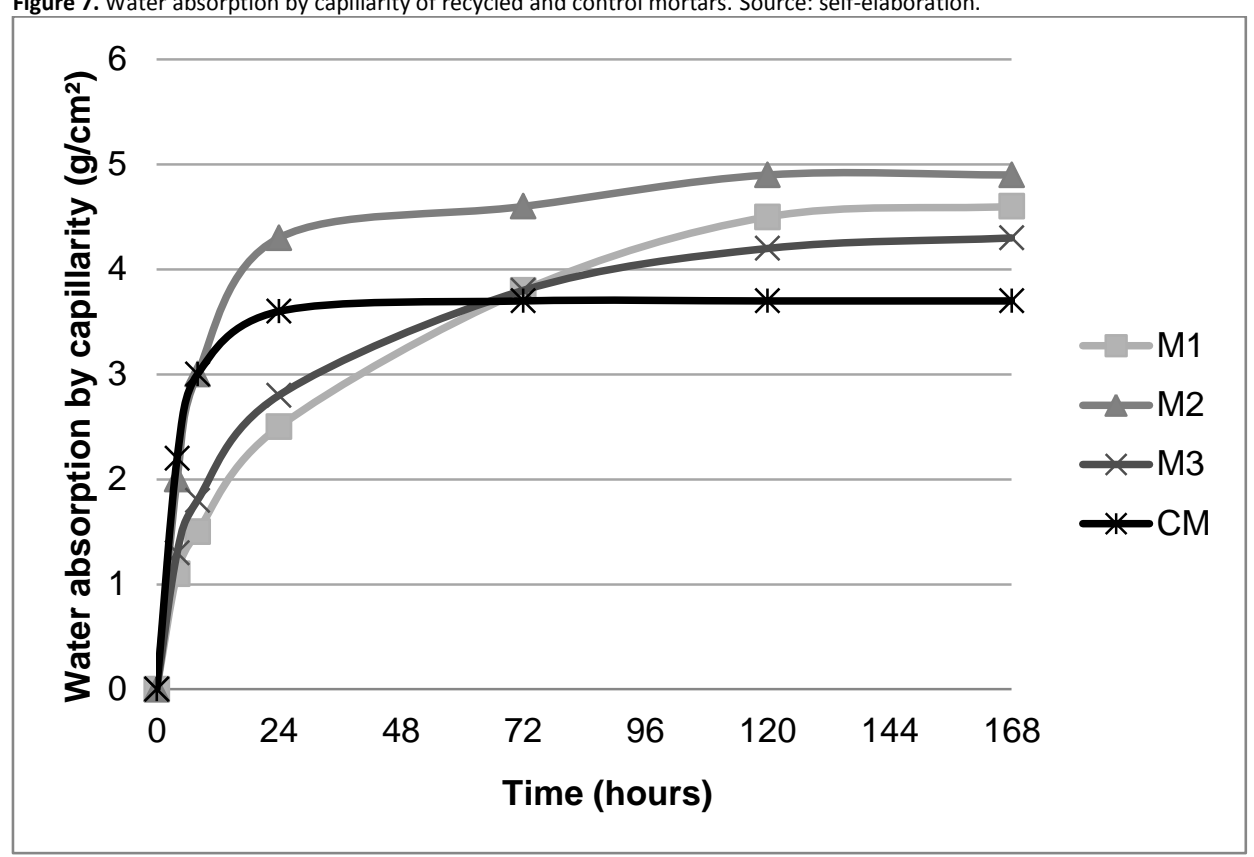

The capillary absorption in the mortars produced with the recycled aggregates was found to be higher than in the mortar produced employing the natural sand aggregate. The reason for the found higher rates of capillary water absorption is a result of the greater number of capillary pores caused by the recycled aggregate mortars' higher water-cement ratio and their increased water absorption capacity.

Similar results have been reported in previous studies where a $100 \%$ substitution of natural aggregates for recycled aggregates have been employed (Martinez, et al, 2013; \& de Brito Silva, 2008). Better behaviour results have been reported on this property when the recycled aggregate mortars were also produced employing mixed recycled aggregates with lower water-cement ratios (Martinez et al., 2013).

The flexural strength of the mortars studied is depicted in Figure 8. The M1 mortar produced employing RA1 recycled aggregates presented similar values to those of the control mortar (CM). However, this was not the case with respect to the M2 and M3 mortars produced employing the RA2 and RA3 recycled aggregates respectively, which showed lower values. The high water absorption of the RA2 and RA3 recycled aggregates could be the cause of the lower flexural strength of these mortars, as analysed in a previous study using recycled aggregates at different levels of pre-saturation (Cuenca-Moyano et al aggregates., 2014 ).

Jimenez et al. (2013) reported values of $2.5 \mathrm{MPa}$ at 28 days (similar to those achieved in the present study), in mortars produced with natural as well as recycled aggregates. This value tends to increase up to $3 \mathrm{MPa}$ at the age of 180 days. 
3

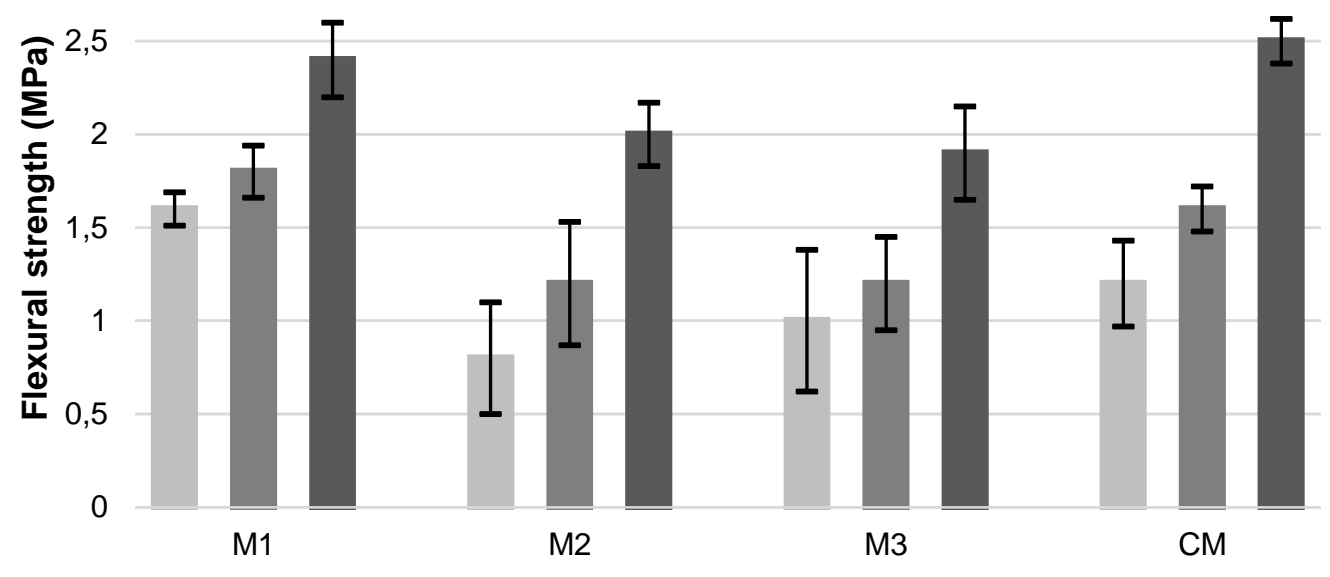

The compressive strength at different ages of all the mortars is indicated in Figure 9, whereas, Figure 10 indicates the relationship of the compressive strength of each of the mortars produced with recycled aggregates with respect to the strength achieved by the control mortar CM.

According to the results obtained by the recycled aggregate mortars, the M2 mortar produced employing RA2 aggregate (obtained from crushing a mainly ceramic residue) reached the highest compressive strength of $6.9 \mathrm{MPa}$ at the age of 28 days. The M1 mortar obtained a strength of $6.6 \mathrm{MPa}$, which was slightly lower than that of the M2. However, this M1 mortar, at younger ages, was the one which proved to have the highest compressive strength (Figure 9).

Although the values of compressive strength obtained by all mortars produced with recycled aggregates were higher than those established by the Cuban standard for type III mortars, all the mortars produced with the recycled aggregates obtained less strength values than that of the control mortar (CM), as can also be observed in various works where the replacement of the natural aggregate was 100\% (Basin-Moyano et al, 2014;. Zhao et al, 2015.).

Figure 9. Compressive strength (average and standard deviation values) of mortars studied at the second stage at 3, 7 and 28 days. The horizontal line show the Cuban regulation minimum permissible value at 28 days. Source: self-elaboration.

$$
\square=7=28
$$

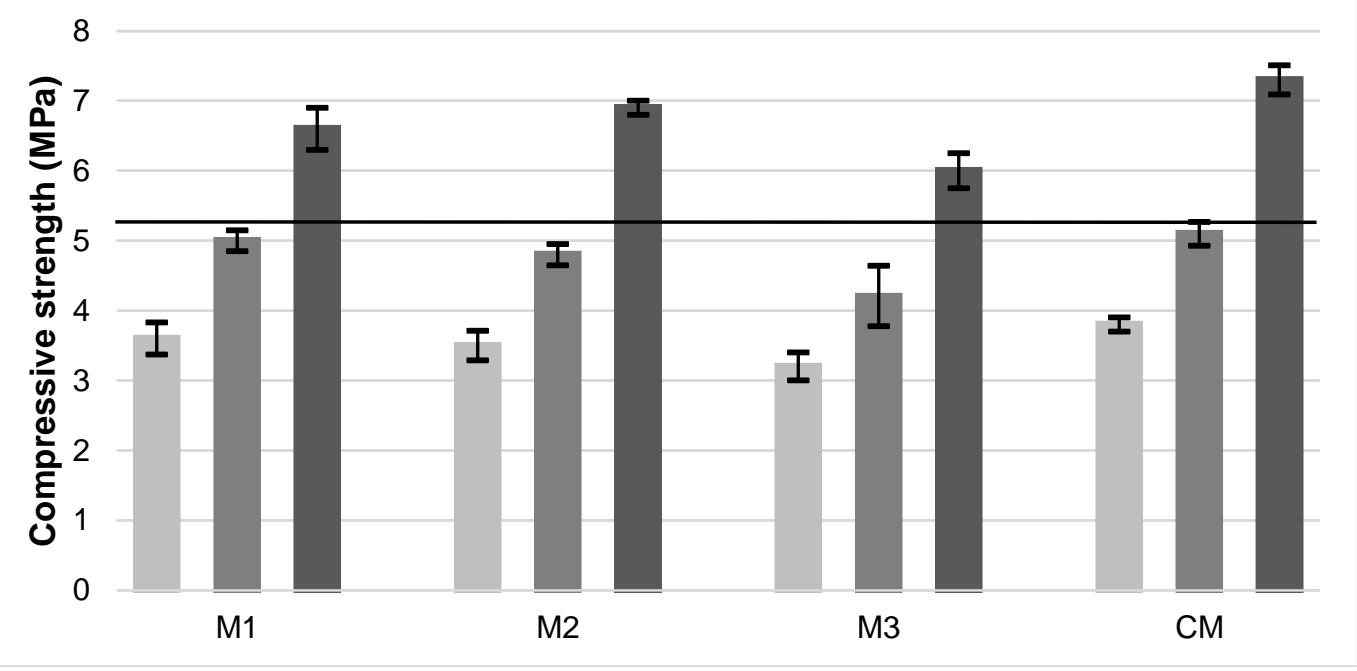


Figure 10. Compressive strength percentage comparison of recycled mortars regarding the Cuban standard and control mortar at 28 days. Source: self-elaboration.

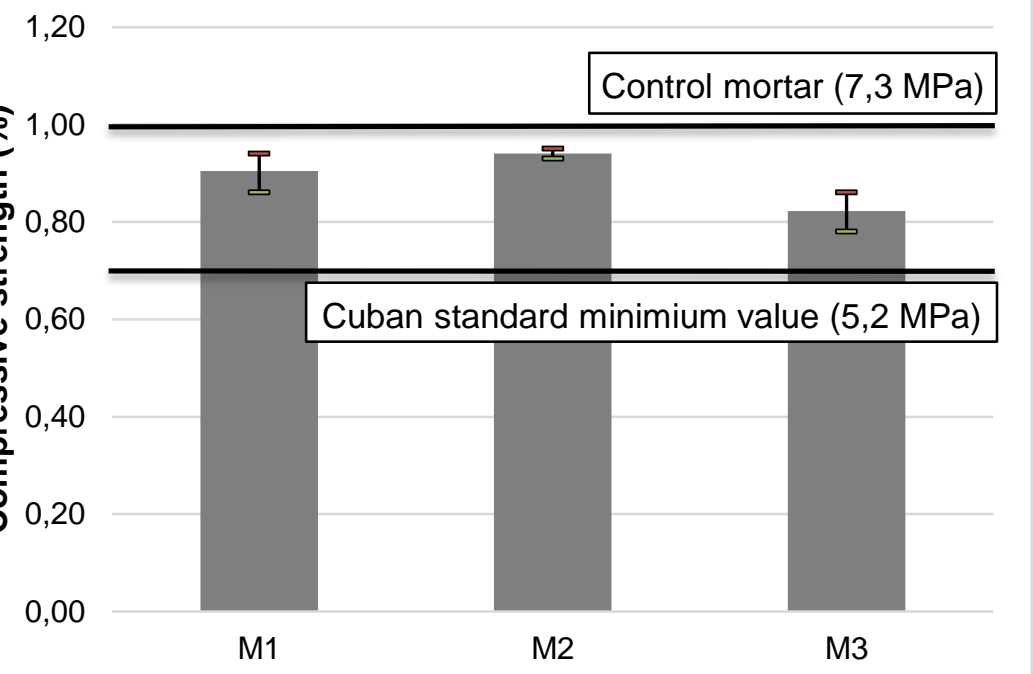

In the work exposed by Vegas et al. (2009) mortars manufactured with recycled aggregate in $100 \%$ substitution of natural sand obtained values of compressive strength of $2.13 \mathrm{MPa}$ at 28 days. However, in the mixing dosage employed the content of recycled aggregate in relation to the cement used was higher.

It has been demonstrated that mortars produced with low percentages of substitution of natural aggregate (up to $40 \%$ ) for recycled ceramic aggregate (Jimenez et al., 2013) or recycled concrete aggregate (Ledesma et al., 2014) may obtain higher compressive strength than conventional mortar. The values obtained in both works were in the range of 7.0 to $8.0 \mathrm{MPa}$, which was slightly higher than those achieved in this study, despite using (the works cited) a lower cement proportion.

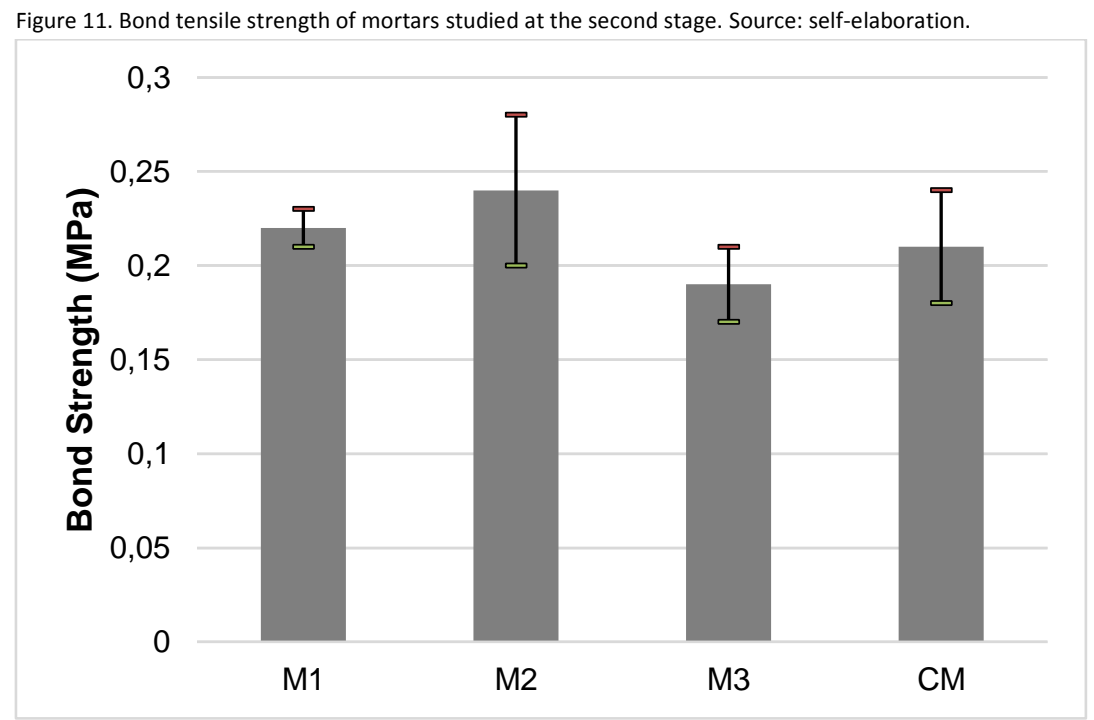

With regard to the minimum required bond strength values for masonry mortars (mortars used for rendering walls), the Cuban regulation stipulates a minimum of $0.2 \mathrm{MPa}$. The M3 mortar was the only recycled aggregate mortar which did not reach these values, reaching values slightly below those permitted (Figure 11). The remaining recycled aggregate mortars reached the minimum required values. Both the $\mathrm{M} 1$ and $\mathrm{M} 2$ mortars, produced from recycled RA1 and RA2 aggregates, respectively, presented bond strength values higher than that of the control CM mortar. These values were slightly lower than those obtained in other studies (Miranda \& Selmo, 2006b;. Paes, et al, 2014).

It should be mentioned that the environment conditions for this property evaluation were extreme. From the moment of its production the mortar under study was left exposed to the environment without curing or additional protection. The low content 
of fine materials present in the RA3 recycled aggregate, together with its high absorption capacity could have an influence on the lower performance achieved by mortar M3.

The large quantity of fine material present within the recycled aggregates used in this research work allow:

- $\quad$ a reduction in the amount of limestone filler employed in the usual dosages of masonry mortars. The optimal volumetric mix proportion was defined as 1: 5: 1 (cement: aggregate: limestone filler) instead of the 1: 4: 2 established for dosages employing only natural aggregates.

- To have a higher water retention value than that of the control mortar $\mathrm{CM}$, which employed only natural sand aggregate.

Although, the compressive strength values of all the recycled aggregate mortars were found to be lower than that of the natural aggregate mortar $\mathrm{CM}$, those values complied with the specifications defined in the Cuban regulation.

In accordance with the test results on the bond tensile strength, it was observed that the mortar produced using mixed recycled aggregate (composed principally of mortar and which showed the highest absorption and had the lowest content of fine material) was the only one which did not reach the minimum strength required by the Cuban regulation. The environmental conditions to which the mortar was exposed during its curing process, without additional protection, could have led to this low value. It is considered, that with minimal care, it would be possible to achieve the minimum value required by Cuban regulations.

The capillary absorption capacity of recycled aggregate mortar is greater than that of natural aggregate mortar, mainly due to the higher absorption capacity of the recycled aggregates, as well as the increase in the water-cement ratio of the recycled aggregate mortars in comparison to the control mortar.

Acknowledgements

The authors wish to thank the Spanish Agency of International Cooperation for Development (AECID) for their continued support to the research project, which gives rise to this present work. The authors would also like to acknowledge the contribution provided by the staff of the construction materials laboratory of the Centre of Construction Studies and Tropical Architecture (CECAT).

\section{References}

Cabrera, J. L. A., Urrutia, F., \& Lecusay, D. (1997). Morteros de albañilería con escombros de demolición. Materiales de Construcción, 47(246), 4348.

Corinaldesi, V. (2010). Mechanical and elastic behaviour of concretes made of recycled-concrete coarse aggregates. Construction and Building Materials, 24(9), 1616-1620. http://doi.org/10.1016/j.conbuildmat.2010.02.031

Corinaldesi, V., \& Moriconi, G. (2009). Behaviour of cementitious mortars containing different kinds of recycled aggregate. Construction and Building Materials, 23(1), 289-294. http://doi.org/10.1016/j.conbuildmat.2007.12.006

Cuenca-Moyano, G. M., Martín-Morales, M., Valverde-Palacios, I., Valverde-Espinosa, I., \& Zamorano, M. (2014). Influence of pre-soaked recycled fine aggregate on the properties of masonry mortar. Construction and Building Materials, 70, 71-79. http://doi.org/10.1016/j.conbuildmat.2014.07.098

Evangelista, L., \& de Brito, J. (2010). Durability performance of concrete made with fine recycled concrete aggregates. Cement and Concrete Composites, 32(1), 9-14. http://doi.org/10.1016/j.cemconcomp.2009.09.005

Jiménez, J. R., Ayuso, J., López, M., Fernández, J. M., \& de Brito, J. (2013). Use of fine recycled aggregates from ceramic waste in masonry mortar manufacturing. Construction and Building Materials, 40, 679-690. http://doi.org/10.1016/j.conbuildmat.2012.11.036

Kou, S. C., \& Poon, C. S. (2012). Enhancing the durability properties of concrete prepared with coarse recycled aggregate. Construction and Building Materials, 35, 69-76. http://doi.org/10.1016/j.conbuildmat.2012.02.032

Ledesma, E. F., Jiménez, J. R., Fernández, J. M., Galvín, A. P., Agrela, F., \& Barbudo, A. (2014). Properties of masonry mortars manufactured with fine recycled concrete aggregates. Construction and Building Materials, 71, 289-298. http://doi.org/10.1016/j.conbuildmat.2014.08.080

Manchón, V. (2010). Estudio de los morteros de colocación y revestimiento preparados con árido fino procedentes del reciclaje de los residuos de construcción y demolición en La Habana Vieja y filler calizo. Instituto Superior Politécnico José Antonio Echeverría.

Martínez, I., Etxeberria, M., Pavón, E., \& Díaz, N. (2012). Evaluación de morteros de albañilería elaborados con áridos reciclados mixtos con diferentes procesos de obtención. Revista Cubana de Ingeniería, 3(2), 2-7. Retrieved from http://rci.cujae.edu.cu/index.php/rci/article/view/64

Martínez, I., Etxeberria, M., Pavón, E., \& Díaz, N. (2013). A comparative analysis of the properties of recycled and natural aggregate in masonry mortars. Construction and Building Materials, 49, 384-392. http://doi.org/10.1016/j.conbuildmat.2013.08.049

Martínez, I., Pavón, E., \& Díaz, N. (2013). Evaluación de las prestaciones de morteros estructurales fabricados con áridos reciclados mixtos de diferente composición. Revista Cubana de Ingeniería, 4(3), 15-21. Retrieved from http://rci.cujae.edu.cu/index.php/rci/article/view/180

Miranda, L. F. R., \& Selmo, S. M. S. (2006a). CDW recycled aggregate renderings: Part I - Analysis of the effect of materials finer than $75 \mu \mathrm{m}$ on mortar properties. Construction and Building Materials, 20(9), 615-624. http://doi.org/10.1016/j.conbuildmat.2005.02.025

Miranda, L. F. R., \& Selmo, S. M. S. (2006b). CDW recycled aggregate renderings: Part II - Analysis of the effect of materials finer than $75 \mu \mathrm{m}$ under accelerated aging performance. Construction and Building Materials, 20(9), 625-633. http://doi.org/10.1016/j.conbuildmat.2005.02.026

Muñoz Fernández, I. (2012). Estudio económico y ambiental del cambio de la gestión de residuos de construcción y demolición en la ciudad de La 
Habana. Universidad Politécnica de Cataluña. Retrieved from http://upcommons.upc.edu/handle/2099.1/14827

Neno, C., Brito, J. De, \& Veiga, R. (2014). Using fine recycled concrete aggregate for mortar production. Materials Research, $17(1), 168-177$. http://doi.org/10.1590/S1516-14392013005000164

Paes, I. N., Bauer, E., Carasek, H., \& Pavón, E. (2014). Influencia del transporte de agua en morteros de revestimiento , en la resistencia a la adherencia Influence of water transportation inside a mortar / block system on bonding resistance behavior. Revista Ingenieria de Construcción, 29(2), 175-186.

Pavón, E., Etxeberria, M., \& Díaz, N. E. (2012). Estudio de la aplicabilidad del hormigón con árido grueso reciclado en La Habana, Cuba. Materiales de Construcción, 62(307), 431-441. http://doi.org/10.3989/mc.2012.63210

Pavón, E., Etxeberria, M., \& Martínez, I. (2011). Propiedades del hormigón de árido reciclado fabricado con adiciones , activa e inerte. Revista de La Construcción, 10(3), 4-15. http://doi.org/10.4067/S0718-915X2011000300002

Pavón, E., Martínez, I., \& Etxeberria, M. (2014). The production of construction and demolition waste material and the use of recycled aggregates in Havana, Cuba. Revista Facultad de Ingeniería, (71), 167-178.

Silva, J., \& de Brito, J. (2008). Argamassas com incorporação de agregados cerâmicos Avaliação do seu desempenho face à água. Teoria E Práctica Na Engenharia Civil, (11), 13-21.

Silva, J., de Brito, J., \& Veiga, R. (2010). Recycled Red-Clay Ceramic Construction and Demolition Waste for Mortars Production. Journal of Materials in Civil Engineering, 22(3), 236-244. http://doi.org/10.1061/(ASCE)0899-1561(2010)22:3(236)

Tabsh, S. W., \& Abdelfatah, A. S. (2009). Influence of recycled concrete aggregates on strength properties of concrete. Construction and Building Materials, 23(2), 1163-1167. http://doi.org/10.1016/j.conbuildmat.2008.06.007

Vegas, I., Azkarate, I., Juarrero, A., \& Frías, M. (2009). Diseño y prestaciones de morteros de albañilería elaborados con áridos reciclados procedentes de escombro de hormigón. Materiales de Construcción, 59(295), 5-18. http://doi.org/10.3989/mc.2009.44207 